\title{
EVALUATION OF CLINICAL EFFICACY OF SINGLE DOSE OF VAGINAL PESSARY SERTACONAZOLE VERSUS CLOTRIMAZOLE IN TREATMENT OF UNCOMPLICATED VAGINAL CANDIDIASIS
}

\author{
Sabitha Umapathy Srinivasan ${ }^{1}$, Hemalatha Reddy², Pradeep Shivaraju ${ }^{3}$ \\ ${ }_{1}^{1}$ Assistant Professor, Department of Obstetrics and Gynaecology, PESIMSR, Andhra Pradesh, India. \\ 2Junior Resident, Department of Obstetrics and Gynaecology, PESIMSR, Andhra Pradesh, India. \\ 3Professor, Department of Obstetrics and Gynaecology, PESIMSR, Andhra Pradesh, India.
}

\section{BACKGROUND}

ABSTRACT

Sertaconazole is a new imidazole fungicide introduced for vulvovaginal candidiasis. It has an azole group with benzothiophene that inhibits biosynthesis of ergosterol and brings about a massive leak of cytoplasm with consequent fungal cell death.

The objective of this study is to evaluate clinical efficacy of single-dose vaginal pessary Sertaconazole versus Clotrimazole in uncomplicated vaginal candidiasis.

\section{MATERIALS AND METHODS}

Patients attending gynaecological and obstetric OPD with a clinical diagnosis of vaginal candidiasis are studied. Vaginal swabs are taken for microscopy and gram staining examination from patients. Patients in Group 1 receives single-dose vaginal pessary Sertaconazole $300 \mathrm{mg}$ and subjects in Group 2 single-dose vaginal pessary Clotrimazole $500 \mathrm{mg}$. Patients are evaluated at the end of 7 days and 28 days for symptomatic relief, side effect and mycological clearance.

Main Outcome Measures: Primary outcome will be clinical cure. Secondary outcome is mycological cure.

Study Design- A prospective, non-randomised, controlled parallel trial.

Setting- PESIMSR, a tertiary referral centre, Kuppam.

\section{RESULTS}

In gynaecological group, $27.3 \%$ of people in sertaconazole group and $77.3 \%$ patients in clotrimazole group had symptoms at the end of 7 days. At the end of 28 days only 15.8\% in sertaconazole group had symptoms, while $55.6 \%$ patients had persisting symptoms in clotrimazole group. Positive vaginal smear was $36.4 \%$ at the end of 7 days of treatment while it was $85.7 \%$ in clotrimazole group and the proportion of positive smear in sertaconazole group at the end of 28 days was $15.8 \%$ while it was $66.7 \%$ in clotrimazole group. On gram staining at the end of 7 days 56.5\% patients in sertaconazole group had no organisms on gram staining, while only $13.0 \%$ in clotrimazole had no organism on smear examination. After 28 days of treatment with $85.0 \%$ in sertaconazole group with no organism on gram staining, while only $33.3 \%$ patients in clotrimazole group became free of organisms. In obstetric group at the end of 7 days only $39.1 \%$ patients in sertaconazole group had symptoms while $66.3 \%$ patients in clotrimazole group and at the end of 28 days $4.8 \%$ in sertaconazole group had symptoms, while all patients had persisting symptoms in clotrimazole group. Positive vaginal smear was $54.5 \%$ at the end of 7 days of treatment, while it was as high as $95.5 \%$ in clotrimazole group. Similarly, the proportion of positive smear in sertaconazole group at the end of 28 days came down to $15.0 \%$, while it was still as high as $50.0 \%$ in clotrimazole group. On gram staining $47.8 \%$ patients in sertaconazole group had no organisms, while only $9.1 \%$ in clotrimazole group had no organisms. After 28 days of treatment with $85.7 \%$ in sertaconazole group with no organism on gram staining, while only $28.6 \%$ patients in clotrimazole group became free of organisms.

\section{CONCLUSION}

In this study, single-dose Sertaconazole was more effective than Clotrimazole in producing symptomatic and mycological clearance in both obstetric and gynaecological group. Because Sertaconazole was given as a single dose, it has additional advantage of better compliance and less emergence of resistance.

\section{KEY WORDS}

Uncomplicated Vaginal Candidiasis, Sertaconazole, Clotrimazole.

HOW TO CITE THIS ARTICLE: Srinivasan SU, Reddy H, Shivaraju P. Evaluation of clinical efficacy of single dose of vaginal pessary sertaconazole versus clotrimazole in treatment of uncomplicated vaginal candidiasis. J. Evolution Med. Dent. Sci. 2018;7(38): 41734177, DOI: $10.14260 /$ jemds/2018/933

'Financial or Other Competing Interest': None.

Submission 02-08-2018, Peer Review 01-09-2018,

Acceptance 07-09-2018, Published 17-09-2018.

Corresponding Author:

Dr. Pradeep Shivaraju,

Professor,

Department of Obstetrics and Gynaecology,

PESIMSR, Kuppam-517425,

Andhra Pradesh, India.

E-mail: drpradi@gmail.com

DOI: $10.14260 /$ jemds $/ 2018 / 933$

(c) $($ ) $\$$

\section{BACKGROUND}

Vaginal candidiasis is a common cause of vaginitis. Although, the disease is rarely life-threatening, it is a source of great physical and psychological discomfort and suffering.(1) It is the most common vaginal infection in women during reproductive age group, also affecting pregnant women.(2) They often present with vaginal discharge.(3) Vaginal candidiasis, an opportunistic mucosal mycosis caused by Candida albicans, is the second most common cause of vaginal inflammation after bacterial vaginosis.(4) Its incidence has increased markedly during the last three decades. The 
incidence of vaginal candidiasis is doubled in the third trimester of pregnancy.(5) Imidazole group of antifungals are commonly used in vaginal candidiasis which includes clotrimazole, fluconazole, isoconazole, oxiconazole, omoconazole and tioconazole.(6) These drugs have limited systemic absorption when used in larger doses and not effective in recurrent chronic vaginal candidiasis.(7) Newer drug sertaconazole used as a single-dose intravaginal pessary has no systemic absorption and is effective in recurrent infections. ${ }^{(8)}$ The patient compliance is better with this drug and is reported to be safe during pregnancy.(9) Single dose therapy has several advantages: significantly improves the compliance to the treatment, reduces the risk of emergence of resistance and reduces side effects. ${ }^{10}$

\section{Aims and Objectives}

- $\quad$ To evaluate the safety and efficacy of a single $300 \mathrm{mg}$ dose of Sertaconazole vaginal pessary in the treatment of uncomplicated vaginal candidiasis.

- To compare with $500 \mathrm{mg}$ single-dose Clotrimazole vaginal pessary.

- Primary outcome will be clinical cure. Secondary outcome is mycological clearance.

\section{MATERIALS AND METHODS}

A study was conducted among 100 patients with uncomplicated vaginal candidiasis, PESIMSR, Kuppam over a period of 1 year from $1^{\text {st }}$ November 2013 to 31 $1^{\text {st }}$ October 2014. As the duration of the study was 1 year, the sample size was taken for convenience. Patients are evaluated at the end of 7 days and 28 days for symptomatic relief, side effect and mycological clearance. Patients were non-randomly allocated in two groups:- 1, 3, 5, 7 in Group 1 and 2, 4, 6, 8...so on in Group 2.

\section{Study Design}

A prospective, non-randomised, controlled parallel trial.

\section{Inclusion Criteria}

- Women belonging to reproductive age group between age 18 - 37 years.

- $\quad$ Pregnant women from $2^{\text {nd }}$ trimester.

- Less than 3 episodes within previous year.

- Microscopy and gram stain showing yeast-like fungi of candida species.

- Those who gave informed and written consent.

\section{Exclusion Criteria}

- Women with bacterial vaginosis, chronic relapsing vulvovaginal candidiasis (more than 3 relapses in 1 year) and sexually transmitted infections.

- Women with severe extragenital pathology (Endocrine disease, state of immunodeficiency).

- Patients who have taken antibiotics during the previous seven days.

- Nursing women.

- Pregnant women in first trimester.

\section{Data Collection}

Patients attending gynaecological and obstetric OPD at PESIMSR with a clinical diagnosis of vaginal candidiasis satisfying the inclusion criteria are randomised into 2 groups alternatively. Vaginal swabs are taken up for microscopy and gram stain.

\section{Direct Microscopic Examination}

Swab was directly examined under a microscope with wet preparation $(10 \% \mathrm{KOH})$ smear on glass slide. The morphological characteristics of budding yeast, pseudohyphae and hyphae were recorded.

\section{Gram Stain}

Vaginal swab is smeared on slide. Crystal violet is added and washed after 1 minute. Slide is washed with Gram's iodine after 30 seconds. Acetone is added and washed immediately. Dilute carbol fuchsin is added to the slide and washed after 30 seconds. Under oil immersion, slide is seen with microscopy.

Patients in Group 1 (50 cases - 25 obstetric and 25 gynaec) received one vaginal pessary Sertaconazole $500 \mathrm{mg}$ deeply into posterior vault of vagina before sleep. Patients of Group 2 (50 cases - 25 obstetric and 25 gynaec) received one vaginal pessary of clotrimazole $500 \mathrm{mg}$. Patients were evaluated for symptomatic clearance, side effect and mycological clearance on $7^{\text {th }}$ and $28^{\text {th }}$ day of treatment.

\section{Data Analysis}

A descriptive and inferential statistical analysis has been carried out in the present study. Results on continuous measurements are presented on Mean \pm SD (Min-Max) and results on categorical measurements are presented in Number (\%). Significance is assessed at 5\% level of significance. The following assumptions on data are made.

\section{Assumptions}

The dependent variables should be normally distributed, 2 samples drawn from the population should be random and cases of the samples should be independent Chi-square/ Fisher Exact test has been used to find the significance of study parameters on categorical scale between two or more groups.

\section{RESULTS}

Age group, parity and socioeconomic status compared between two treatment groups among Gynaecological patients.

\begin{tabular}{|c|c|c|c|c|c|c|}
\hline \multirow{2}{*}{$\begin{array}{l}\text { Sl. } \\
\text { No. }\end{array}$} & \multirow[t]{2}{*}{ Parameter } & \multicolumn{4}{|c|}{\begin{tabular}{l|l} 
Sertaconazole & Clotrimazole \\
Group $(\mathrm{N}=25)$ & Group $(\mathrm{N}=25)$ \\
\end{tabular}} & \multirow[t]{2}{*}{ P value } \\
\hline & & No. & $\%$ & No. & $\%$ & \\
\hline 1. & Age group & & & & & \\
\hline (a) & $20-29$ & 9 & 36.0 & 9 & 36.0 & \multirow{3}{*}{0.56 ; NS } \\
\hline (b) & $30-39$ & 13 & 52.0 & 15 & 60.0 & \\
\hline (c) & $40-49$ & 3 & 12.0 & 1 & 4.0 & \\
\hline 2. & Parity & & & & & \\
\hline (a) & Nullipara & 6 & 24.0 & 4 & 16.0 & \multirow{4}{*}{$0.70 ; \mathrm{NS}$} \\
\hline (b) & One & 3 & 12.0 & 5 & 20.0 & \\
\hline (c) & Two & 7 & 28.0 & 9 & 36.0 & \\
\hline (d) & $\begin{array}{c}\text { Three and } \\
\text { above }\end{array}$ & 9 & 36.0 & 7 & 28.0 & \\
\hline 3. & $\begin{array}{c}\text { Socioeconomi } \\
\text { Status }\end{array}$ & & & & & \\
\hline (a) & Middle & 9 & 36.0 & 7 & 28.0 & \multirow{2}{*}{0.54 ; NS } \\
\hline (b) & Low & 16 & 64.0 & 18 & 72.0 & \\
\hline
\end{tabular}


Majority of the gynaecological patients belonged to 30-39 years' age group in both the treatment groups $(52.0 \%$ in sertaconazole and $60.0 \%$ in clotrimazole group). Majority of the patients had parity of 2 or 3 in both the treatment groups. A large proportion of the patients in both groups $(64.0 \%$ in sertaconazole group and $72.0 \%$ in clotrimazole group) belonged to low socioeconomic status. Overall, the age distribution, parity and socioeconomic status were similar in the treatment groups with no statistically significant differences between them making them comparable.

Symptoms, per speculum examination findings and organisms isolated compared between two treatment groups among Gynaecological patients.

\begin{tabular}{|c|c|c|c|c|c|c|}
\hline \multirow{2}{*}{$\begin{array}{l}\text { Sl. } \\
\text { No. }\end{array}$} & \multirow{2}{*}{ Parameter } & \multicolumn{2}{|c|}{$\begin{array}{l}\text { Sertaconazole } \\
\text { Group }(\mathrm{N}=25)\end{array}$} & \multicolumn{2}{|c|}{$\begin{array}{c}\text { Clotrimazole } \\
\text { Group }(\mathrm{N}=25)\end{array}$} & \multirow{2}{*}{$\begin{array}{c}P \\
\text { value }\end{array}$} \\
\hline & & \begin{tabular}{|c|} 
No. of \\
Patients
\end{tabular} & $\%$ & \begin{tabular}{|c|} 
No. of \\
Patients
\end{tabular} & $\%$ & \\
\hline 1. & Symptoms & & & & & \\
\hline (a) & $\begin{array}{c}\text { Vaginal } \\
\text { discharge }\end{array}$ & 25 & 100.0 & 25 & 100.0 & \begin{tabular}{|c|}
$1.00 ;$ \\
NS \\
\end{tabular} \\
\hline (b) & Pain abdomen & 25 & 100.0 & 25 & 100.0 & $\begin{array}{c}1.00 \\
\text { NS }\end{array}$ \\
\hline (c) & Foul smelling & 10 & 40.0 & 10 & 40.0 & $\begin{array}{c}1.00 \\
\text { NS }\end{array}$ \\
\hline (d) & Itching & 6 & 24.0 & 7 & 28.0 & $\begin{array}{c}0.75 \\
\text { NS }\end{array}$ \\
\hline 2. & Per Speculum & & & & & \\
\hline (a) & $\begin{array}{c}\text { Curdy white } \\
\text { discharge }\end{array}$ & 25 & 100.0 & 25 & 100.0 & $\begin{array}{c}1.00 \\
\text { NS }\end{array}$ \\
\hline (b) & Foul smelling & 10 & 40.0 & 9 & 36.0 & $\begin{array}{c}0.77 \\
\text { NS }\end{array}$ \\
\hline (c) & Hyperaemia & 9 & 36.0 & 9 & 36.0 & $\begin{array}{c}1.00 \\
\text { NS }\end{array}$ \\
\hline
\end{tabular}

In both the treatment groups of gynaecological patients, vaginal discharge and pain abdomen were universal, while foul smelling was found in $40.0 \%$ patients and itching in around $25.0 \%$ patients. Similarly on speculum examination, curdy white discharge was universal, while foul smelling was found in around $40.0 \%$ and hyperaemia in $36.0 \%$ patients. The organism mainly isolated in both the treatment groups was mostly Candida albicans (88.0\% in sertaconazole group and $96.0 \%$ in clotrimazole group). The proportion of symptoms, findings on speculum examination and organism isolated were similar between the two treatment groups with no statistically significant differences.

\section{Organisms Isolated}

\begin{tabular}{|c|c|c|c|c|c|c|}
\hline & $\begin{array}{c}\text { Organism } \\
\text { Isolated }\end{array}$ & \multicolumn{4}{|c|}{} \\
\cline { 1 - 5 } (a) & $\begin{array}{c}\text { Candida } \\
\text { albicans }\end{array}$ & 22 & 88.0 & 24 & 96.0 & $0.29 ;$ \\
(b) & $\begin{array}{c}\text { Candida } \\
\text { glabrata }\end{array}$ & 3 & 12.0 & 1 & 4.0 & NS \\
\hline
\end{tabular}

In both the treatment groups of gynaecological patients, the organism mainly isolated in both the treatment group was mostly Candida albicans (88.0\% in sertaconazole group and $96.0 \%$ in clotrimazole group). The proportion of organism isolated were similar between the two treatment groups with no statistically significant differences.

\begin{tabular}{|c|c|c|c|c|c|c|}
\hline \multirow[t]{2}{*}{$\begin{array}{l}\text { Sl. } \\
\text { No. }\end{array}$} & \multirow[t]{2}{*}{ Parameter } & \multicolumn{2}{|c|}{$\begin{array}{l}\text { Sertaconazole } \\
\text { Group }(\mathrm{N}=25)\end{array}$} & \multicolumn{2}{|c|}{$\begin{array}{c}\text { Clotrimazole } \\
\text { Group } \\
(\mathrm{N}=25)\end{array}$} & \multirow[t]{2}{*}{$P$ value } \\
\hline & & No. & $\%$ & No. & $\%$ & \\
\hline 1. & $\begin{array}{c}\text { Symptoms at } \\
\text { the end of } 7 \\
\text { days }\end{array}$ & & & & & \\
\hline (a) & Present & 6 & 27.3 & 17 & 77.3 & \multirow{2}{*}{$\begin{array}{c}<0.001 ; \\
\text { S }\end{array}$} \\
\hline (b) & Absent & 16 & 72.7 & 5 & 22.7 & \\
\hline 2. & \begin{tabular}{|c|} 
Symptoms at \\
the end of 28 \\
days
\end{tabular} & & & & & \\
\hline (a) & Present & 3 & 15.8 & 10 & 55.6 & \multirow{2}{*}{$0.011 ; S$} \\
\hline (b) & Absent & 16 & 84.2 & 8 & 44.4 & \\
\hline & Side Effects & & & & & \\
\hline (a) & Nil & 17 & 85.0 & 19 & 82.6 & \multirow{2}{*}{0.83 ; NS } \\
\hline (b) & Mild irritation & 3 & 15.0 & 4 & 17.4 & \\
\hline & $\begin{array}{l}\text { atmptomatic Im } \\
\text { atmong }\end{array}$ & $\begin{array}{l}\text { aprov } \\
\text { g the }\end{array}$ & $\begin{array}{l}\text { ent an } \\
\text { dy Gro } \\
\text { ients }\end{array}$ & ide & ects d & $\begin{array}{l}\text { ing } \\
\text { gical }\end{array}$ \\
\hline
\end{tabular}

Symptomatic improvement was significantly better with those gynaecological patients treated by sertaconazole group. At the end of 7 days only $27.3 \%$ patients in sertaconazole group had symptoms, while $77.3 \%$ patients in clotrimazole group continued to suffer from symptoms. At the end of 28 days only $15.8 \%$ in sertaconazole group had symptoms, while $55.6 \%$ patients had persisting symptoms in clotrimazole group. The proportion of side effects was also relatively lower in sertaconazole group with only $15.0 \%$ patients suffering from mild irritation, while $17.4 \%$ patients in clotrimazole group had mild irritation. Thus, clinical improvement was significantly better in sertaconazole group compared to clotrimazole.

\begin{tabular}{|c|c|c|c|c|c|c|}
\hline \multirow{2}{*}{$\begin{array}{l}\text { Sl. } \\
\text { No. }\end{array}$} & \multirow{2}{*}{$\begin{array}{c}\text { Fungi on } \\
\text { Microscopy }\end{array}$} & \multicolumn{2}{|c|}{$\begin{array}{l}\text { Sertaconazole } \\
\text { Group }(\mathrm{N}=25)\end{array}$} & \multicolumn{2}{|c|}{$\begin{array}{c}\text { Clotrimazole } \\
\text { Group } \\
(\mathrm{N}=25)\end{array}$} & \multirow[t]{2}{*}{ P value } \\
\hline & & $\begin{array}{c}\text { No. of } \\
\text { Patients }\end{array}$ & $\%$ & \begin{tabular}{|c|} 
No. of \\
Patients
\end{tabular} & $\%$ & \\
\hline 1. & \begin{tabular}{|c|} 
After \\
treatment of \\
7 days \\
\end{tabular} & & & & & \\
\hline (a) & Present & 8 & 36.4 & 18 & 85.7 & $<0.001$ \\
\hline (b) & Absent & 14 & 63.6 & 3 & 14.3 & $S$ \\
\hline 2. & $\begin{array}{c}\text { After } \\
\text { treatment } \\
\text { for } 28 \text { days }\end{array}$ & & & & & \\
\hline (a) & Present & 3 & 15.8 & 12 & 66.7 & 0.002 \\
\hline (b) & Absent & 16 & 84.2 & 6 & 33.3 & $\mathrm{~S}$ \\
\hline
\end{tabular}

Age group, parity and socioeconomic status compared between two treatment groups among obstetric patients.

\begin{tabular}{|c|c|c|c|c|c|c|}
\hline \multirow{2}{*}{$\begin{array}{l}\text { Sl. } \\
\text { No. }\end{array}$} & \multirow{2}{*}{ Parameter } & \multicolumn{2}{|c|}{$\begin{array}{l}\text { Sertaconazole } \\
\text { Group }(\mathrm{N}=25)\end{array}$} & \multicolumn{2}{|c|}{$\begin{array}{l}\text { Clotrimazole } \\
\text { Group }(N=25)\end{array}$} & \multirow{2}{*}{\begin{tabular}{|c|}
$P$ \\
value
\end{tabular}} \\
\hline & & \begin{tabular}{|c|} 
No. of \\
Patients
\end{tabular} & $\%$ & $\begin{array}{c}\text { No. of } \\
\text { Patients }\end{array}$ & $\%$ & \\
\hline 1. & Age Gr & & & & & \\
\hline (a) & $20-24$ & 18 & 72.0 & 17 & 68.0 & \\
\hline (b) & $25-29$ & 5 & 20.0 & 5 & 20.0 & \\
\hline (c) & 30 and above & 2 & 8.0 & 3 & 12.0 & \\
\hline
\end{tabular}




\begin{tabular}{|c|c|c|c|c|c|c|}
\hline 2. & Gravida & & & & & \\
\hline (a) & Primigravida & 14 & 56.0 & 13 & 52.0 & \multirow{3}{*}{$\begin{array}{c}0.91 \\
\text { NS }\end{array}$} \\
\hline (b) & Second & 8 & 32.0 & 8 & 32.0 & \\
\hline (c) & $\begin{array}{c}\text { Third and } \\
\text { above gravida }\end{array}$ & 3 & 12.0 & 4 & 16.0 & \\
\hline 3. & $\begin{array}{c}\text { Socioeconomic } \\
\text { Status }\end{array}$ & & & & & \\
\hline (a) & High & 2 & 8.0 & 0 & 0.0 & 0.33 \\
\hline (b) & Middle & 8 & 32.0 & 10 & 40.0 & NS \\
\hline (c) & Low & 15 & 60.0 & 15 & 60.0 & \\
\hline
\end{tabular}

Mycological Clearance during Treatment in Study Groups of Gynaecological Patients

Majority of the obstetric patients belonged to $20-24$ years' age group in both the groups $(72.0 \%$ in sertaconazole and $68.0 \%$ in clotrimazole group). Majority of the patients were primigravida (56.0\% in sertaconazole group and $52.0 \%$ in clotrimazole group). A large proportion of the patients in both groups $(60.0 \%$ in both groups) belonged to low socioeconomic status. Overall, the age distribution, parity and socioeconomic status were similar in the treatment groups with no statistically significant differences between them making them comparable.

Symptoms, per speculum symptoms and per speculum examination findings and organisms isolated were compared between two treatment groups among obstetric patients.

\begin{tabular}{|c|c|c|c|c|c|c|}
\hline \multirow{2}{*}{$\begin{array}{r}\text { Sl. } \\
\text { No. }\end{array}$} & \multirow{2}{*}{ Parameter } & \multicolumn{2}{|c|}{$\begin{array}{c}\text { Sertaconazole } \\
\text { Group (N=25) }\end{array}$} & \multicolumn{2}{c|}{$\begin{array}{c}\text { Clotrimazole } \\
\text { Group (N=25) }\end{array}$} & \multirow{2}{*}{ P value } \\
\cline { 3 - 7 } & $\begin{array}{c}\text { No. of } \\
\text { Patients }\end{array}$ & $\%$ & $\begin{array}{c}\text { No. of } \\
\text { Patients }\end{array}$ & \% & \\
\hline 1. & Symptoms & \multicolumn{5}{|c|}{} \\
\hline (a) & $\begin{array}{c}\text { Vaginal } \\
\text { discharge }\end{array}$ & 25 & 100.0 & 25 & 100.0 & $1.00 ; \mathrm{NS}$ \\
\hline (b) & Itching & 25 & 100.0 & 22 & 88.0 & $0.07 ; \mathrm{NS}$ \\
\hline (c) & Pain abdomen & 15 & 60.0 & 13 & 52.0 & $0.56 ; \mathrm{NS}$ \\
\hline (d) & $\begin{array}{c}\text { Burning } \\
\text { sensation }\end{array}$ & 7 & 28.0 & 9 & 36.0 & $0.54 ; \mathrm{NS}$ \\
\hline (e) & Dyspareunia & 4 & 16.0 & 3 & 12.0 & $0.68 ; \mathrm{NS}$ \\
\hline & & & & & & \\
\hline 2. & $\begin{array}{c}\text { Per } \\
\text { Speculum }\end{array}$ & & & & & \\
\hline (a) & $\begin{array}{c}\text { Curdy white } \\
\text { discharge }\end{array}$ & 25 & 100.0 & 25 & 100.0 & $1.00 ; \mathrm{NS}$ \\
\hline (b) & Hyperaemia & 8 & 32.0 & 12 & 48.0 & $0.25 ; \mathrm{NS}$ \\
\hline (c) & Foul smelling & 6 & 36.0 & 6 & 36.0 & $1.00 ; \mathrm{NS}$ \\
\hline
\end{tabular}

In both the treatment groups of gynaecological patients, vaginal discharge was universal. While all patients in sertaconazole group had itching, $88.0 \%$ in clotrimazole group patients had itching. Pain abdomen was found in $60.0 \%$ of sertaconazole group and $52.0 \%$ of clotrimazole group. The other symptoms like burning sensation and dyspareunia were similar in the two treatment groups. Similarly, on speculum examination, curdy white discharge was universal, while foul smelling and hyperaemia was similar in the treatment groups. The organism isolated in both the treatment group was Candida albicans. The proportion of symptoms, findings on speculum examination and organism isolated were similar between the two treatment groups with no statistically significant differences.

\begin{tabular}{|c|c|c|c|c|c|c|}
\hline \multicolumn{7}{|c|}{ Organism Isolated } \\
\hline & $\begin{array}{c}\text { Organism } \\
\text { Isolated }\end{array}$ & & & & & \\
\hline (a) & $\begin{array}{l}\text { Candida } \\
\text { albicans }\end{array}$ & 25 & 100.0 & 25 & 100.0 & 1.00; NS \\
\hline
\end{tabular}

In both the treatment groups of gynaecological patients, the organism isolated in both the treatment groups was Candida albicans. The proportion of organisms isolated were similar between the two treatment groups with no statistically significant differences.

\begin{tabular}{|c|c|c|c|c|c|c|}
\hline \multirow{2}{*}{$\begin{array}{l}\text { Sl. } \\
\text { No. }\end{array}$} & \multirow[t]{2}{*}{ Parameter } & \multicolumn{2}{|c|}{$\begin{array}{l}\text { Sertaconazole } \\
\text { Group }(\mathrm{N}=25)\end{array}$} & \multicolumn{2}{|c|}{\begin{tabular}{|c|}
$\begin{array}{c}\text { Clotrimazole } \\
\text { Group } \\
(\mathrm{N}=25)\end{array}$ \\
\end{tabular}} & \multirow[t]{2}{*}{ P value } \\
\hline & & \begin{tabular}{|c|} 
No. of \\
Patients \\
\end{tabular} & $\%$ & \begin{tabular}{|c|} 
No. of \\
Patients
\end{tabular} & $\%$ & \\
\hline 1. & $\begin{array}{c}\text { Symptoms } \\
\text { at the end } \\
\text { of } 7 \text { days }\end{array}$ & & & & & \\
\hline (a) & Present & 9 & 39.1 & 16 & 66.3 & 0.06 ; \\
\hline (b) & Absent & 14 & 60.9 & 8 & 33.3 & NS \\
\hline 2. & $\begin{array}{l}\text { Symptoms } \\
\text { at the end } \\
\text { of } 28 \text { days } \\
\end{array}$ & & & & & \\
\hline (a) & Present & 1 & 4.8 & 21 & 100.0 & $<0.001$ \\
\hline (b) & Absent & 20 & 95.2 & 0 & 0.0 & $S$ \\
\hline 3. & Side Effects & & & & & \\
\hline (a) & Nil & 22 & 100.0 & 18 & 85.7 & \\
\hline (b) & $\begin{array}{c}\text { Mild } \\
\text { irritation }\end{array}$ & 0 & 0.0 & 3 & 14.3 & $\begin{array}{c}0.00 \\
\text { NS }\end{array}$ \\
\hline
\end{tabular}

Mycological clearance during treatment in study groups of Obstetric patients.

\begin{tabular}{|c|c|c|c|c|c|c|}
\hline \multirow{2}{*}{$\begin{array}{l}\text { Sl. } \\
\text { No. }\end{array}$} & \multirow{2}{*}{$\begin{array}{l}\text { Fungi on } \\
\text { Microscopy }\end{array}$} & \multicolumn{2}{|c|}{$\begin{array}{l}\text { Sertaconazole } \\
\text { Group }(\mathrm{N}=25)\end{array}$} & \multicolumn{2}{|c|}{$\begin{array}{c}\text { Clotrimazole } \\
\text { Group }(\mathrm{N}=25)\end{array}$} & \multirow{2}{*}{$\begin{array}{c}P \\
\text { value }\end{array}$} \\
\hline & & \begin{tabular}{|c|} 
No. of \\
Patients
\end{tabular} & $\%$ & \begin{tabular}{|c|} 
No. of \\
Patients
\end{tabular} & $\%$ & \\
\hline 1. & $\begin{array}{c}\text { After } \\
\text { treatment for } \\
7 \text { days } \\
\end{array}$ & & & & & \\
\hline (a) & Present & 12 & 54.5 & 21 & 95.5 & 0.0017 \\
\hline (b) & Absent & 10 & 45.5 & 1 & 4.5 & ;S \\
\hline 2. & \begin{tabular}{|c|} 
After \\
treatment for \\
28 days \\
\end{tabular} & & & & & \\
\hline (a) & Present & 3 & 15.0 & 10 & 50.0 & \\
\hline (b) & Absent & 17 & 85.0 & 10 & 50.0 & $0.02 ; \mathrm{S}$ \\
\hline
\end{tabular}

\section{DISCUSSION}

Vulvovaginal candidiasis occurs in at least $40 \%$ of adult women at any given point and possibly in most women at some time during their adult life. In our study highest incidence of vaginal candidiasis is among primigravida, which is consistent with other studies. In our study, incidence of symptoms of vaginal candidiasis was vaginal discharge (100\%), pain abdomen (100\%), foul smelling (40\%), itching (24\%) and of signs was curdy white discharge (100\%), foul smelling (40\%) and hyperaemia (36\%). Symptomatic improvement was significantly better with gynaecological patients treated by sertaconazole group. At the end of 7 days 
only $27.3 \%$ patients in sertaconazole group had symptoms, while $77.3 \%$ patients in clotrimazole group continued to suffer from symptoms. At the end of 28 days only $15.8 \%$ in sertaconazole group had symptoms, while $55.6 \%$ patients had persisting symptoms in clotrimazole group. Thus, clinical improvement was significantly better in sertaconazole group compared to clotrimazole.

In our study, symptomatic improvement was significantly better with those obstetric patients treated by sertaconazole group. At the end of 7 days only $39.1 \%$ patients in sertaconazole group had symptoms, while $66.3 \%$ patients in clotrimazole group continued to suffer from symptoms. At the end of 28 days only $4.8 \%$ in sertaconazole group had symptoms, while all patients had persisting symptoms in clotrimazole group. Thus, clinical improvement was significantly better in sertaconazole group compared to clotrimazole group. In the present study none of the patients in sertaconazole group had suffered from any side effect, while as much as $85.7 \%$ patients in clotrimazole group had mild irritation.

\section{CONCLUSION}

In our study to evaluate the safety and efficacy of single-dose intravaginal pessary Sertaconazole $300 \mathrm{mg}$, with single-dose intravaginal pessary Clotrimazole $500 \mathrm{mg}$ in treating uncomplicated vaginal candidiasis, Sertaconazole was found to be more effective than Clotrimazole.

In this study, Sertaconazole showed better symptomatic and microbiological clearance compared to Clotrimazole. The major advantage is that the emergence of resistance is less with Sertaconazole, which can also be attributed to its single dose administration which is curative.

Another advantage is cross resistance, which is a minimal with Sertaconazole as it is not related to other antibiotics. Side effects reported were only minor, such as mild irritation at the time of insertion which was self-limiting.

The purpose of our study is to stress on the treatment of uncomplicated vaginal candidiasis with an antibiotic which has better compliance and has activity against various candida species. Resistance to multiple drugs is a growing concern worldwide and hence treatment should be directed towards prescribing a drug which is least likely to cause emergence of resistance.

\section{REFERENCES}

[1] Sobel JD, Faro S, Force RW, et al. Vulvovaginal candidiasis: epidemiologic, diagnostic and therapeutic considerations. Am J Obstet \& Gynecol 1998;178(2):203-11.

[2] Horowitz BJ, Giaquinta D, Ito S. Evolving pathogens in vulvovaginal candidiasis: implications for patient care. J Clin Pharmacol 1992;32(3):248-55.

[3] Cotch MF, Hillier SL, Gibbs RS, et al. Epidemiology and outcomes associated with moderate to heavy Candida colonization during pregnancy. Vaginal Infections and Prematurity Study Group. Am J Obstet Gynecol 1998;178(2):374-80.

[4] Rad MM, Zafarghandi AS, Zabihi AM, et al. Identification of Candida species associated with vulvovaginal candidiasis by multiplex PCR. Infectious Diseases in Obstetrics and Gynecology 2012;2012:p. 5.

[5] Fidel PL Jr, Sobel JD. Immunopathogenesis of recurrent vulvovaginal candidiasis. Clin Microbiol Rev 1996;9(3):335-48.

[6] Barousse MM, Espinosa T, Dunlap K, et al. Vaginal epithelial cell anti-Candida albicans activity is associated with protection against symptomatic vaginal candidiasis. Infect Immun 2005;73(11):77657.

[7] Nowakowska D, Kurnatowska A, Stray-Pedersen B, et al. Prevalence of fungi in the vagina, rectum and oral cavity in pregnant diabetic women: relation to gestational age and symptoms. Acta Obstet Gynecol Scand 2004;83(3):251-6.

[8] Sobel JD. Vulvovaginal Candidosis. Lancet 2007;369(9577):1961-71.

[9] Carrillo-Munoz AJ, Tur-Tur C, Giusiano G, et al. Sertaconazole: an antifungal agent for the topical treatment of superficial candidiasis. Expert Rev Anti Infect Ther 2013;11(4):347-58.

[10] Achkar JM, Fries BC. Candida infections of the genitourinary tract. Clin Microbiol Rev 2010;23(2):253-73. 